удК $\quad 316.728(497.115) " 1918 / 1941 "$

94:79(497.115)"1918/1941"

DOI https://doi.org/10.31212/tokovi.2019.3.sla.53-78

Оригинални научни рад

Примљен: 8. 2. 2019.

Прихваћен: 3. 9.2019.

\author{
Božica SLAVKOVIĆ MIRIĆ \\ Institute for Recent History of Serbia, Belgrade \\ bozica.slavkovic@gmail.com
}

\title{
Clothing and Entertainment in Kosovo and Metohija between the Two World Wars*
}

\begin{abstract}
With the help of relevant literature and press, this paper analyzes and describes the mentality and behavior of people in Kosovo and Metohija in the period between the two world wars. The way of life was determined by a mainly agrarian existence on small farms, and by cultural and educational backwardness of the population, especially in the countryside. It was hard to adopt modern influences from nearby towns, because farmers jealously guarded their way of life, customs, and traditions. However, positive qualities such as hospitality and humor, and also colorful costumes, traditions, a great number of different customs and folk literature, are some of the important features of the population of Kosovo and Metohija preserved to this day.
\end{abstract}

Key words: Kosovo and Metohija, The Interwar Period, Clothing, Entertainment, Everyday Life

\section{Introduction}

Under Ottoman rule, Serbian-Albanian relations and everyday life in Kosovo and Metohija were determined by the privileged Albanian position. ${ }^{1}$ Albanian autonomist ideas were also significant, realized in

* This article is a contribution to the project Transition and transformation - Historical Heritage and National Identity in Serbia in the $20^{\text {th }}$ Century, No 47019, financed by the Ministry for education, science and technological development of the Republic of Serbia.

1 Miloš Jagodić, Srpsko-albanski odnosi u Kosovskom vilajetu (1878-1912), (Beograd: Zavod za udžbenike, 2009), 1-9. 
the provisions of the League in Prizren and the League in Peć. ${ }^{2}$ The Serbian people were not legally protected and often migrated. ${ }^{3}$ The Serbian Government tried to protect its population by opening consulates, arming the population, and demanding reforms by the Ottoman Empire. ${ }^{4}$ The New Ottoman Government of "the Young Turks" (Mladoturci) did not contribute to the resolution of the situation. The Albanian leaders wanted to pursue their national interests. ${ }^{5}$

In the First Balkan War, Kosovo and Metohija were exempt from Turkish rule. According to the provisions of the Bucharest Peace Treaty of 1913, Kosovo and part of Metohija with Prizren became part of the Kingdom of Serbia, while Peć, Đakovica, and Istok in Metohija became part of the Kingdom of Montenegro. ${ }^{6}$ After the Second Balkan War, the "new areas" (novi krajevi) were adjoined to Serbia. ${ }^{7}$ This area was in an unstable situation, economically and politically, (only $17 \%$ of the land was cultivated and Albanians and Turks made up almost $30 \%$ of the population in South Serbia). ${ }^{8}$ The most difficult task of the Kingdom of Serbia was to regulate the attitude of Albanians toward the state, because the majority did not want to accept losing the privileges they had in the Ottoman Empire.

$2 \quad$ Jovan Hadži-Vasiljević, Arbanaska liga: arnautska kongra i srpski narod u Turskom Carstvu (1878-1882), (Beograd: Uredništvo Ratnika, 1909); Miloš Vojvodić, „Berlinski kongres i Prizrenska liga“, Istorijski glasnik 1-2/1989, 1-20; Bogumil Hrabak, „Ideje o arbanaškoj autonomiji i nezavisnosti 1876-1880“, Istorijski časopis XXII-XXIII (1978-1979), 159-192; Bernard Stulli, Albansko pitanje (1875-1882), (doktorska disertacija, Filozofski fakultet, Sveučilište u Zadru).

3 Đorđe Mikić, Društvene i ekonomske prilike kosovskih Srba u XIX i početkom XX veka: od čifčijstva do bankarstva, (Beograd: SANU, 1988), 26.

4 For more information, see: Dušan Bataković, Pokušaj otvaranja srpskog konzulata u Prizrenu (1898-1900), (Beograd: Istorijski institut, 1984), 249-259; Radovan Samardžić i dr., Kosovo i Metohija u srpskoj istoriji, (Beograd: Srpska književna zadruga, 1989); Savremenici o Kosovu i Metohiji: 1852-1912, prir. Dušan T. Bataković, (Beograd: Srpska književna zadruga, 1988); Vladimir Stojančević, Srbi i Arbanasi 1804-1912, (Novi Sad: Prometej, 1994); Dušan T. Bataković, Istraga oružja u Ibarskom Kolašinu 1901. godine, (Beograd, 1990), 269-284.

5 Bogumil Hrabak, „Kosovo prema Mladoturskoj revoluciji 1908”, Obeležja 5/1974, 107-149.

6 Đorđe Mikić, „Albanci i Srbija u Balkanskim ratovima 1912-1913“, Istorijski glasnik 1-2/1986, 60; Radošin Rajović, Autonomija Kosova: istorijsko-pravna studija, (Beograd: Ekonomika, 1985), 31.

7 Miloš Jagodić, Uređenje oslobođenih oblasti Srbije: 1912-1914: pravni okvir, (Beograd: Istorijski institut, 2010), 31.

8 Atanasije Urošević, „Agrarna reforma i naseljavanje“, Spomenica 25-godišnjice oslobođenja Južne Srbije, 819-833, (Skoplje: Odbor za proslavu dvadesetpetogodišnjice oslobođenja Južne Srbije, 1937), 819. 
During World War I, the Serbian-Albanian border was unstable. The Albanian population of Kosovo, Metohija, and Western Macedonia, saw the war as an opportunity to become free from the Serbian state. ${ }^{9}$ After the war, it was not easy to re-establish power and return the Albanian population to peacetime life. It was necessary to establish military and police authorities, secure roads, and disarm the unpredictable Albanian population. ${ }^{10}$

The decade before the emergence of the personal regime of King Aleksandar, South Serbia was characterized by cultural deprivation, national separation, economic underdevelopment, traffic disconnection with other parts of the country, insufficient state control, tolerance of financial and legal fraud, and a restless border with neighboring Albania.

In 1921 the territory of Kosovo and Metohija was part of the province of North and South Serbia. In the Kingdom of Serbs, Croats, and Slovenes, the territory of Kosovo and Metohija became part of the district of Prizren (Prizren municipality and districts of Gora, Podgora, Podrima, Has, and Šarplanina), Metohija (municipality of Peć and districts of Đakovica, Istok, and Peć), Zvečan (municipality of Kosovska Mitrovica and districts of Vučitrn, Drenica, and Mitrovica), and part of Skoplje (district of Kačanik). ${ }^{11}$ The first general census, conducted on 31 January 1921, showed that the province of South Serbia had 439,010 registered inhabitants. In terms of native language, 113,848 (26.6\%) were Serbs, 278,411 (65.0\%) Albanians, and 27,910 (6.5\%) Turks. In terms of confession, there were 349,028 (74.4\%) Muslims, 92,951 (21.7\%) Serbian Orthodox, 15,783 (3.7\%) Catholics, and 510 miscellaneous. ${ }^{12}$

9 Dimitrije Bogdanović, Knjiga o Kosovu, (Beograd: SANU, 1986), 218; Živko Avramovski, „Granice Kraljevine SHS sa Albanijom“, Istorija 20. veka 1-2/1992, 40; Andrej Mitrović, „Albanci u politici Austro-Ugarske prema Srbiji 1914-1918“, Srbi i Albanci u XX veku, prir. Andrej Mitrović, (Beograd: SANU, 1991), 79-104.

10 Bogumil Hrabak, Dragoslav Janković, Srbija 1918, (Beograd: Sedma sila, 1968), 181183. For more information, see: Dmitar Tasić, Rat posle rata: Vojska Kraljevine Srba, Hrvata i Slovenaca na Kosovu i Metohiji i u Makedoniji: 1918-1920, (Beograd: Utopija, Institut za strategijska istraživanja, 2008), 29-53; Ljubodrag Dimić, Đorđe Borozan, Jugoslovenska država i Albanci, tom 1, (Beograd: Službeni list SRJ, Arhiv Jugoslavije, Vojno-istorijski institut, 1998).

11 Vladimir Simeunović, Stanovništvo Jugoslavije i socijalističkih republika: 1921-1961: ukupno stanovništvo, polna i starosna struktura, (Beograd: Savezni zavod za statistiku, 1964), 16, 23; Goran Nikolić, „Kretanje stanovništva Kosova i Metohije između dva svetska rata“, Nova srpska politička misao, 2006 (debate), datum pristupa 14. 6. 2019, http://starisajt.nspm.rs/Debate/2006_nikolic_kos33.htm

12 Definitivni rezultati popisa stanovništva po maternjem jeziku od 31. januara 1921, (Beograd: Opšta državna statistika, 1932); Milenko Filipović, „Etničke prilike u Južnoj Srbiji“, Spomenica 25-godišnjice oslobođenja Južne Srbije, priredio Aleksa Jovanović, 
On 26 April 1922, the country was divided into 33 regions. The territory of Kosovo and Metohija became a part of the Kosovo, Raška, Zeta, and Skoplje districts. ${ }^{13}$ After instituting dictatorship in 1929, the Kingdom of Yugoslavia was divided into nine provinces (banovine). Kosovo and Metohija became part of the Vardar Banovina (districts of Gnjilane, Gora, Gračanica, Kamenik, Nerodimlje, Podgora and Šar planina), the Zeta Banovina (districts of Drenica, Đakovica, Istok, Kosovska Mitrovica, Peć, and Podrima), and the Morava Banovina (districts of Lab and Vučitrn). ${ }^{14}$ The general census conducted on 31 March 1931 showed 552,064 registered inhabitants on the territory of Kosovo and Metohija; $(67,045$ or $4.67 \%$ in the Morava Banovina), 276,245 or $17.55 \%$ in the Vardar Banovina, and 208,774 or $22.56 \%$ ) in the Zeta Banovina. ${ }^{15} \mathrm{~A}$ total of 331,549 $(60.01 \%)$ inhabitants declared themselves as Albanians and 179,524 $(32.05 \%)$ as Serbs. ${ }^{16}$

Regarding ownership structure, the Kingdom of Yugoslavia was a country of small peasant estates. ${ }^{17}$ The way of life and the use of leisure time were defined by the fact that a large percentage of the people was living in rural areas and were engaged in agriculture $(76.30 \%) .{ }^{18}$ Over $90 \%$ of the agricultural households in Kosovo and Metohija were in the districts of: Gora (94.05\%), Drenica (92.82\%), and Podgora (92.18\%). ${ }^{19}$ The District of Kosovska Mitrovica had a minimum of agricultural households (57.22\%). As for the vocational structure, according to the census of 1931, the agricultural population was dominant (mostly Drenica district, 98.04\%). The majority of the population in Kosovska Mitrovica (9.03\%) was engaged in trade and traffic, indicating that Kosovska Mitrovica was a developed urban center. Kosovo and Metohija had a young age structure (26.6\% in 1921 and $24.9 \%$ in 1931), due to a high birth rate from

(Skoplje: Odbor za proslavu dvadesetpetogodišnjice oslobođenja Južne Srbije, 1937), 428-431.

13 Službene novine Kraljevine SHS, br. 22, (Beograd), 1922.

14 „Zakon o nazivu i podeli kraljevine na upravna područja“, Zbirka Službenog glasnika, sv. XXXVI, (Split, 1929), 4-5; Politika, br. 7694, 4. 10. 1929, 3; Politika, br. 8375, 3. 9. 1931, 3.

15 Simeunović, Stanovništvo Jugoslavije i socijalističkih republika, 27.

16 Nikolić, „Kretanje stanovništva Kosova i Metohije“.

17 Ljubodrag Dimić, Kulturna politika Kraljevine Jugoslavije, knj. 1, (Beograd: Stubovi kulture, 1996), 25.

18 Božica Slavković Mirić, Političke, ekonomske i kulturne prilike na Kosovu i Metohiji 1929-1941, (Beograd: IP Prosveta, IP Princip, 2018), 225.

19 Definitivni rezultati popisa stanovništva od 31. marta 1931, knj. 4, (Beograd: Opšta državna statistika, 1940), 183, 269-291, 317-333. 
1921 to $1931 .{ }^{20}$ As for gender structure, men prevailed (50.2\% in 1921 and $50.9 \%$ in 1931). It was because in the patriarchal and traditional society, male children were more appreciated than female. ${ }^{21}$

The unstable political situation in Kosovo and Metohija, caused by the expansion of the idea of a Greater Albania, influenced the mood of the Serbian population of this area. ${ }^{22}$ In order to solve problems, the Serbian state tried to modernize the population, especially in the army. Recruits were educated in hygiene; they traveled by rail for the first time, saw the city, and went to a theater or cinema. The military leadership insisted on developing roads and railways, and military doctors were often the only ones where there were no civilian doctors. ${ }^{23}$

The situation with education, illiteracy, social habits, and social structure of the towns greatly affected the daily life of the population. It was essential to regulate the school system, build, rebuild, and equip schoolhouses, bring adequate teaching staff, urge parents to send their children to school regularly. Illiteracy was very high. In Kosovo and Metohija in 1931 it was $84.2 \%$ (93.9\% among women) of the illiterate population (older than 10 years). ${ }^{24}$ Albanian society was conservative, not ready to accept the state's educational policy. The patriarchal customs, living in fis (clans) and fraternities, tribal consciousness, remnants of feudal production and archaic concepts contributed to the isolation of Albanian society. ${ }^{25}$

The agrarian reform and colonization affected everyday life. The agrarian reform abolished the feudal system, which had a moral and economic effect. The colonization of Kosovo and Metohija (by people from Vojvodina, Lika, Dalmatia) had an impact on changing the aspect of the village. They built houses that expressed their culture, traditions and heritage. ${ }^{26}$ The life of settlers was also affected by the uncertainty and fear of

20 Simeunović, Stanovništvo Jugoslavije i socijalističkih republika, 110.

21 Ibid., 62-63.

22 Slavković Mirić, Političke, ekonomske i kulturne prilike na Kosovu i Metohiji, 146-160.

23 Mile Bjelajac, Vojska Kraljevine SHS: 1918-1921, (Beograd: Narodna knjiga, 1988), 263.

24 Dragomir Bondžić, „Učitelji u multietničkim sredinama: primer Kosova i Metohije 1945-50", Obrazovanje i uloga učitelja u srpskom društvu kroz istoriju (XVIII-XX vek), (Sombor: Pedagoški fakultet, 2009), 21-22; Osnovni statistički podaci o razvoju i stanju školstva u Federativnoj Narodnoj Republici Jugoslaviji: dokumentacija uz Deklaraciju o sistemu obrazovanja i vaspitanja u FNRJ, (Beograd: Savezna Narodna skupština, 1957), 3-10.

25 Ljubodrag Dimić, Kulturna politika Kraljevine Jugoslavije, knj. 3, (Beograd: Stubovi kulture, 1996), 125.

26 Milorad Obradović, Agrarna reforma i kolonizacija na Kosovu 1918-1941, (Priština: Institut za istoriju Kosova, 1981), 221; Aleksandar Pavlović, „Naselja Srba i Crnogoraca 
Albanian "kachak" 27 attacks. Adam Pribićević believed that, at that time, greater resolution was required to go to Kosovo, Drenica, and Metohija, than to the United States. ${ }^{28}$ However, the arrival of settlers strengthened the national consciousness of the native population. They brought a more intensive and modern agricultural system, improved social and hygienic habits, and developed households. ${ }^{29}$ Also, the settlers began to develop cooperatives, libraries, reading rooms, and theater performances. ${ }^{30}$

In the interwar period, there was great progress in the regulation of the towns and in the prevention and treatment of diseases, but they were still lacking in water supply, sanitation, electrification, school buildings, hospital buildings, hygienic apartments, and parks. ${ }^{31}$ The population in the cities engaged in agriculture, which meant that urban areas were in a transition between town and village. ${ }^{32}$ Also, the urban centers depended on the development of communication links. Due to the construction of railways and roads, Uroševac, Obilić, and Peć became significant, while Prizren and Đakovica declined due to the closure of the border with Albania. ${ }^{33}$

The political, economic, and cultural situation in Kosovo and Metohija between the two world wars affected the daily life of the population and the manner of their dress and behavior in the city and in the countryside.

\section{Leisure and Entertainment in the Countryside}

The rural population of Kosovo and Metohija did not know the concept of leisure and entertainment; they spent the time that remained after

kolonizovanih na Kosovu i Metohiji u periodu između 1918 i 1941“, Baština 25/2008, 228.

27 Kachaks ("kačaci") is a term used for the Albanian bandits active in the late 19th and early 20th century in northern Albania, Montenegro, Kosovo and Macedonia, and later as a term for the militias of Albanian revolutionary organizations against the Kingdom of Serbia (1910-18) Kingdom of Yugoslavia (1918-24), called the "Kachak movement" (Dragi Maliković, Kačački pokret na Kosovu i Metohiji 1918-1924, (Priština: Institut za srpsku kulturu, 2005)).

28 Adam Pribićević, Od gospodina do seljaka, (Zagreb: Srpsko kulturno društvo Prosvjeta, 1996), 132; Đorđe Krstić, Kolonizacija u Južnoj Srbiji, (Sarajevo: Đ. Krstić, 1928), 74.

29 Krstić, Kolonizacija u Južnoj Srbiji, 73-95.

30 Pribićević, Od gospodina do seljaka, 140-143.

31 Vardar, 7. jul 1934, 2.

32 Pravda, 26. oktobar 1937.

33 Milivoje Savić, Naša industrija i zanati, VII deo, (Beograd: Izdanja Ministratvsa trgovine i industrije, 1929), 164-166. 
strenuous daily tasks resting and sleeping. Time orientations were sowing, plowing, scything and harvesting, and New Year was in October. ${ }^{34}$ In winter they spent time by the fire; the host would take the gusle and sing epic folk songs, and they told interesting stories or solved riddles. Politician and publicist Adam Pribićević, who lived in this area as a colonist, believed that the high cost of gas was a major cause of the ignorance of the rural population. The farmer could read when he had less work, during the autumn and winter nights, but he had to save gas. This was the reason why peasants went from house to house to gather together "so that gas could be spread evenly". ${ }^{35}$

The hospitality in the countryside was an important and necessary feature. Albanians in Kosovo and Metohija considered every person as a guest regardless of their age, gender, ethnic or social affiliation. The village of Rugova's hospitality was famous, even though the place was very poor. They even received Montenegrins although they had "always been on the warpath" with them. ${ }^{36}$ The inhabitants of Podgora were also very welcoming and friendly people. ${ }^{37}$ Hospitality in Gnjilane was evenly developed among Serbs and Albanians. The Serbs visited their family only during major holidays and the slava - family patron saint's day feast - while the Albanians were more likely to visit without any special reason. Serbs immediately introduced their guest into the house and the host and the other male members stayed with him, but the Albanians' guests had to knock on the door for "the women" to move away, and the guest was led away into the visitor's room. For all Albanians, it was their duty to welcome guests, but it was not only a welcoming meal, like with the Serbs, but the guest was surrounded by attention and talking - everyone gathered around the guest, sitting cross-legged, passing the tobacco box to each other. That conversation was wide-ranging. "Anyone with a guest, even if he saw him for the first time, exchanged almost identical greetings several times. He would ask about personal health, then the health of the parents, brothers, friends, etc." In the presence of Serbian guests, they sang Serbian songs. The singer was usually accompanied by one on ćitelija, a two-wire tambura, and they played on kavale, facing each other. If the guest was staying overnight, they would prepare the guest room for him.

34 Vladan Jovanović, „Istorijsko, svakodnevno i privatno na prostoru Vardarske banovine“, Privatni život kod Srba u dvadesetom veku, (Beograd: Clio, 2007), 569.

35 Pribićević, Od gospodina do seljaka, 301.

36 Grigorije Božović, Slike Kosova i Metohije, (Priština: Narodna i univerzitetska biblioteka, 1998), 75.

37 Ibid., 103. 
Albanians had better furniture in the guest rooms, but the bed in Serbian homes was clean and tidy, while the Albanians' "although it was finer, sometimes smelled because it was dirty." Serbs would leave the guest to sleep alone in the room, but with Albanians, a member of the household remained, usually the host. ${ }^{38}$ The guest would be escorted on departure. ${ }^{39}$

The central gathering of people was the celebration of the slava and holidays. The slava was one of the most distinctive Serbian customs, when friends and relatives gathered, "reconciled their feuds and remembered poor people." ${ }^{40}$ Each house had two slavas, one in the spring (preslava) and the other in the fall or winter. Those who celebrated the same slava were as relatives. A slava in Metohija was called svetoga or sveti. The host would send a family member to invite neighbors, but friends were invited with a toast, which consisted of a bottle of wine, bread, apples and basil. The celebration was on the eve of the slava when they performed rituals at home, and broke the slava bread before the arrival of the priest. The next day there was a lunch. At the slava, folk songs of Serbian heroes and historical figures were sung and gusle were played. During the slava the host and the men served guests; they were not allowed to sit and were bareheaded as a sign of respect to the saint. ${ }^{41}$

A family and tribal slava was a custom that was also practiced by Catholic Serbs and Catholic Albanians. They celebrated the slava in the same way, the only difference being they did not cut the slava bread. On 4 January 1934, on page 8, Vardar magazine states that some Muslim Serbs in Sredačka Župa, Drenica, and Rugova also held this tradition; "they knew what their ancestors were celebrating," on that day they did not work, some received guests and lit candles. Also, Muslims attended the slava of their Orthodox Serb neighbors or acquaintances. ${ }^{42}$

38 Atanasije Urošević, O Kosovu - antropogeografske studije i drugi spisi, (Priština: Narodna i univerzitetska biblioteka „Ivo Andrić“, Institut za srpsku kulturu, Gnjilane: Knjižara „Sveti Sava“, 2001), 55-57. For more information, see: Кадри Халими, „Белешке о обичају госторимства код Албанаца на Косову“, Гласник Музеја Косова (10), (Приштина), 1970, 345-353; Петар Влаховић, „Народно гостопримство на Косову и Метохији“, Рад 14. Конгреса Савеза фолклориста Југославије у Призрену, (Београд, 1967), 151-155.

39 Petar Vlahović, „Etnološke odrednice Kosova i Metohije“, Zbornik radova Kosovo $i$ Metohija u svetlu etnologije, (Beograd: Etnografski muzej: Muzej u Prištini, Centar za očuvanje nasleđa Kosova i Metohije - Mnemosyne, 2004), 220-228.

40 Branislav Nušić, Kosovo, (Priština: Panorama, 2007), 170-176.

41 Mitar Vlahović, „Etnološka promatranja na Kosovu polju“, Južni pregled, 11. novembar 1930, 574-577.

42 Mitar Vlahović, „Sredačka župa“, Zbornik za etnografiju i folklor Južne Srbije i susednih oblasti, knj. 1, (Skoplje: Štamparija Vasilija Dimitrijevića, 1931), 27-52. More about 
The Serbs also celebrated "name day." Guests came by for "coffee and brandy." Most solemnly celebrated was the name day of Božidar on Christmas Day (Božić), when guests were served food as well. They did not celebrate birthdays because there were many members of the family and they felt that if everyone celebrated their birthday, the family "would not have bread to eat." Celebrating birthdays was only reserved for firstborn sons, and later celebrating birthdays started in the urban areas of Kosovo and Metohija, which was a tradition adopted from the newcomers from various parts of Yugoslavia: officials, workers and colonists. ${ }^{43}$

In the villages, the Church slava was celebrated (the saint to whom the local church was consecrated), as well as the sabor (when the people gathered at the church or elsewhere on a holiday), and the "procession" (litija), which was held on certain days for more abundant crops and fruits. On these days, there were sofras (food was served) for all people and especially for the guests; girls would sing and young men competed in sporting and jousting games. The host of the slava was usually someone very prominent, because he was supposed to organize this feast, which entailed a considerable cost (roast lamb or pig, many liters of different brandies, wine, and slava bread). This was a big day for children, since their parents would buy them sweets and they were not required to go to school or herd livestock. For the rural youth, the days of the sla$v a$ were the most joyous, because they sang from morning to night, and danced the kolo, a local folk dance to the music of the zurle and goč - traditional instruments. ${ }^{44}$ The men displayed skillful moves and daring jumps in the kolo, while the women were modest and restrained. ${ }^{45}$

In the long nights of late autumn and winter, gatherings called prelo were organized, primarily in homes. Girls then embroidered, crocheted, knitted or spun together, singing all the while. Until the introduction of electricity, they used oil lamps. Benches were set in two rows, in one sat the girls and in another the boys. Prelas lasted no later than midnight. ${ }^{46}$

albanian families and their costumes: Марк Краснићи, „Шиптарска породична задруга у Косовско-метохијској области“, Гласник Музеја Косова и Метохије (45), (Приштина), 1959-1960, 137-171; Мирко Барјактаровић, „Породична задруга Бали Чуке из Ругове“, Гласник музеја Косова и Метохије (1), (Приштина), 1956, 275-283; Мирко Барјактаровић, „Двовјерске шиптарске задруге у Метохији“, Зборник радова ЕИ САНУ (1), (Београд, 1950), 197-209.

43 Tatomir Vukanović, Srbi na Kosovu, knj. 2, (Vranje: Nova Jugoslavija, 1986), 182-183.

44 M. Vlahović, „Etnološka promatranja na Kosovu polju“, 574-577.

45 Vukanović, Srbi na Kosovu, knj. 2, 179.

46 Petar Denda, Pavle Ivanov Dželetović, Suvi Do, (Beograd: Odbor za proučavanje sela SANU, 1993), 33. 
Another type of mainly female fun pastime and an interesting folk phenomenon, especially in the villages, was singing folk songs while turning a pan on the table or on the floor. With Albanians that custom was very popular and was widespread from Peć to Djakovica. ${ }^{47}$ It was considered that singing folk songs in that way sounded the most beautiful in the Albanian language. The Turks also had this custom and it was thought that, in addition to its entertainment features, it had a magical effect. ${ }^{48}$

\section{Entertainment in Towns - Cinemas, Theaters, Societies}

The appearance of the cinema was very important for the development of cultural and entertainment life in the towns of Kosovo and Metohija. In Yugoslavia in 1933 there were 338 cinemas including 15 in the Vardar Banovina. ${ }^{49}$ In Kosovska Mitrovica there were three cinemas Jadran, Pariz, and Palas, ${ }^{50}$ and in Priština, the cinema Edison, which featured newly produced films. ${ }^{51}$ The first film was screened at the hotel Jadran in 1928. In the beginning, those were silent films but soon apparatus with celluloid arrived that had music and speech recorded. The first sound film was shown in 1931, "Paramount's Love Parade". The first sound film in domestic production "Oj letni, Sivi Sokole" was shown in 1934. That year "The funeral of King Alexander I The Unifier" ("Pogreb Blaženopoč. Kralja Aleksandra I Ujedinitelja") also came out, which was seen by "a large number of citizens and soldiers, as well as pupils of primary and secondary schools".$^{52}$ All film screenings happened in full movie theaters: Jadran had 150 seats, Palas 200, and Pariz 100. The repertoire and advertisements were published in local newspapers. Screenings were organized four times a week, and if necessary, two or three times a day. The majority of films were American and German, and also Czechoslovakian, French, and Russian. Gangster and cowboy movies were shown, as well as movies with sensational adventure contents. Most of these films

47 Tatomir Vukanović, „O pevačima narodnih pesama u Drenici“, Prilozi proučavanju narodne poezije (1, sv. 3), 1934, 156-158.

48 Tatomir Vukanović, „Pevanje narodnih pesama uz okretanje tepsije“, Glasnik muzeja Kosova i Metohije (1), 1956, 118-157.

49 Jovanović, „Istorijsko, svakodnevno i privatno na prostoru Vardarske banovine“, 569.

50 Jovan Aleksić, „Srpska novinska glasila u Kosovskoj Mitrovici od 1918 do 1941. godine“, Hronotop Kosova i Metohije u nauci i umetnosti, (Leposavić: Institut za srpsku kulturu, 2018), 494.

51 Jovanović, „Istorijsko, svakodnevno i privatno na prostoru Vardarske banovine“, 570.

52 Ali Hadri, „Društveno-ekonomske, političke, kulturno-prosvetne i zdravstvene prilike“, Kosovska Mitrovica i okolina, 107-110, (Priština: Institut za istoriju Kosova, 1979), 173. 
had no artistic value, because the theater owners were trying to adapt to the taste of a wide audience..$^{53}$ However, farmers viewed motion pictures as an "extravagance and a luxury." 54

As for the theater, the first theater event organizers were students and teachers of grammar school in Kosovska Mitrovica, a town which in the interwar period had become the cultural center of Kosovo and Metohija. There were also amateur theaters and the selection of theater plays was dictated by the ability of the actors, director, halls, and audiences who wanted entertainment, and not an artistic textual experience. Therefore, first in the repertoire were comedies, for example those written by Branislav Nušić. At the beginning, the theater groups operated without government aid and without adequate facilities, so performances were staged in hotel halls. In the early 1930s, with the development of the Trepča mining complex, cultural life had become more diverse. English management of the mining company influenced the modernization of the population. The Workers' Cultural Artistic Society "Abrašević" had its own theater troupe, which performed their first play in front of the miners. In March of 1939, the plays "Bury the Dead" by Irwin Shaw and "Micro and the Tax Collector" ("Mikro i poreznik") by Živorad Mihajlović were held. ${ }^{55}$ The football club "Zvečan" had a theater section as well. In early 1937, at the initiative of cultural workers Pavlimir Gligorijević, Milovan Vuksanović, and Risto Durgutović, an independent theater association was established, called "Božur sa Kosova." The repertoire included comedies by Nušić and Sterija Popović and was shown in Priština, Vučitrn, Peć, Uroševac, and Novi Pazar. ${ }^{56}$ In 1930, the "Nušić" Singing Society was founded with its civil-ecclesiastical choir of about 60 members. A singing club with a long tradition was the "Car Uroš" Society in Prizren (founded in 1885). According to the newspaper Vardar of October 23, 1936 on page 2, this society performed in Peć in 1931 and toured throughout Serbia in October of 1936.

Many culture clubs toured for several days in Kosovska Mitrovica. Thus, the cultural and artistic societies "Građevinar" and "Abrašević" from Skoplje were visiting and performances were held at the Hotel "Pariz." Satirical pieces, such as "Đavolja posla" and "Iz ljubavi u smrt"

53 Zoran Vukadinović, Milovan Bogavac, Srpska prosveta i kultura u Kosovskoj Mitrovici: 1836-1941, (Priština: Institut za srpsku kulturu, 2001), 194-195.

54 Vukanović, Srbi na Kosovu, knj. 2, 203.

55 Hadri, „Društveno-ekonomske, političke, kulturno-prosvetne i zdravstvene prilike“, 176.

56 Vukadinović, Bogavac, Srpska prosveta i kultura u Kosovskoj Mitrovici, 82-184. 
were shown. ${ }^{57}$ In June 1933, The "Obilić" Singing Society held a concert in Kosovska Mitrovica on a tour of the Vardar, Zeta, and Morava Banovinas ${ }^{58}$ At the "Sokolski dom" in Kosovska Mitrovica, a cultural-artistic group from Belgrade, the Serbian Church Choral Society of Pančevo, appeared in October $1938^{59}$ and, while on a tour of southern Serbia, held concerts in Kosovska Mitrovica and Priština. ${ }^{60}$ Cultural and artistic groups of students from the University of Belgrade organized events in all the major towns of Kosovo and Metohija. ${ }^{61}$

All societies, clubs and associations had their slavas and organized matinees, parties, balls, and costume parties. The "Trepča" Music Society (founded in 1937) appeared every Thursday and Sunday with its tambura orchestra in the garden of the "London" Restaurant. ${ }^{62}$ Every year artisan entertainment was organized, which was one of the most popular and most visited in the city. There were balls organized "which were more luxurious then balls in much larger cities. Then the hotel halls were converted into gardens, tropical exotic areas, with hundreds and hundreds of balloons, lanterns and colored lights." Ladies wore "extravagant ball gowns" and gentlemen "black suits and tuxedos." The abundance and variety of cultural life was also enriched by events organized by the Russian and English colonies on religious holidays. ${ }^{63}$ The first symphony concert was held on 1 March 1935 and was performed by the musicians of the $24^{\text {th }}$ and $31^{\text {st }}$ Infantry Regiments (works of Beethoven and Tchaikovsky), and the audience was thrilled. At the invitation of English engineers, famous jazz orchestras from Europe and the United States appeared in Kosovska Mitrovica, but they performed at closed parties with expensive tickets. ${ }^{64}$

57 Hadri, „Društveno-ekonomske, političke, kulturno-prosvetne i zdravstvene prilike“, 173-174.

58 Momčilo Pavlović i dr., Kosovo i Metohija: vek važnih događaja: 1912-2012, (Beograd: Instutut za savremenu istoriju, 2012), 43.

59 Ibid., 50.

60 Ibid., 47.

61 Ibid., 48.

62 Hadri, „Društveno-ekonomske, političke, kulturno-prosvetne i zdravstvene prilike“, 173-174.

63 Vukadinović, Bogavac, Srpska prosveta i kultura u Kosovskoj Mitrovici, 200-201.

64 Ibid., 188-192. 


\section{The Manner of Dress and Behavior in the Countryside and in Towns}

Serbs and Albanians as neighbors had great similarities in their behavior, but they also showed some differences. Serbs, outside their village, and even in town, had been seen "in their underpants and shirts," while Albanians considered that as indecent. Women were withdrawn; none "engaged freely in conversation with their neighbors" or "looked at or greeted unknown passers-by." Muslim women in villages with a mixed population appeared with a covered head. In cases where the whole village was Muslim and from one fis, there was no need for that, because no one could marry a woman of the same fis. ${ }^{65}$ Also, Albanians rarely cursed because of their patriarchal view on life, but "when it did come to that, then a whole stream of insults and slander poured out, which could cause a fistfight and sometimes even cause a blood feud". ${ }^{66}$

Both Serbs and Albanians cut their hair. Serbs and Catholic Albanians shaved their beards, while the Muslims grew beards when they were older as a sign of seriousness. ${ }^{67}$ Body tattooing and dyeing hair (bojadisanje) was common. They tattooed mainly initials or a full personal name, as well as religious motifs (a Muslim crescent with the star and a Christian cross). This kind of tattooing was found only in men. Men were usually tattooed while working abroad (pečalba).$^{68}$ With the Albanian Muslims, for example, in Priština, the women were tattooed on their hands and feet. Tattooing was widespread among Albanians in Vučitrn, especially in the army, but there were also cases in Prizren. ${ }^{69}$ Dyeing hair, nails and fingers was a common custom among Muslims in the Kosovo-Metohija area. In Kosovo it was also a habit among the Serbian women. Black dye was applied for the first time before marriage and afterwards the hair was regularly dyed black until death. Dyeing hair was done on Fridays and therefore the Serbs in Vučitrn called Friday "dye." Blonde hair in the Kosovo towns could generally not be seen. For hair dyeing they used a "mass that was called mazi (oak tree cones) in Turkish, and dispersion (antimony) was added." In the village of Kojlovica, near Priština, the Serb

65 Atanasije Urošević, Gornja Morava i Izmornik, (Priština: Jedinstvo, 1993), 137-142.

66 Tatomir Vukanović, Drenica - druga srpska Sveta Gora, (Priština: Muzej u Prištini, Narodna i univerzitetska biblioteka, 1998), 190-191, 201-203.

67 Urošević, Gornja Morava i Izmornik, 137-142.

68 Vukanović, Srbi na Kosovu, knj. 2, 138.

69 Milenko Filipović, „Tetovisanje u Južnoj Srbiji“, Godišnjak skopskog Filozofskog fakulteta (2), 1936, 76-95. 
women were making color by frying "freshly baked butter until it turned black and added basil to the butter for a better smell."70

Village life had neither the time nor the place for fashion. Adam Pribićević described farmers not having time for making clothes due to too much work, and when they went into town to shop, they bought the cheapest materials and cloth and wore them "until they fell apart." ${ }^{\prime 1}$ However, younger generations were ready for change, whose impact was felt and spread from nearby towns. Vardar Magazine of 28 September 1936 wrote on page 5 about rural fashion being a "social evil" - "Fashion is an infective national disease and farmers work all year to obtain clothes for their daughter or son. Instead of giving in to fashion, the farmer should dedicate himself to buying tools and working the land."

\section{National Costume - Ethnographic and National Symbol of Kosovo and Metohija}

National costumes in Kosovo and Metohija had long been present in dressing as a result of a patriarchal culture and stood out for their beauty and diversity. ${ }^{72}$ The way of dressing was related to the economy and welfare of the community. Traditional clothing was supposed to build a national awareness and integrate the community. So, the settlers abandoned their way of dressing and wore almost identical clothes as the natives. Costumes emphasized strict regional and group endogamy, indirectly pointed to the social status of the individual, their age and religious affiliation. Regional and ethnic characteristics of folk costumes were retained until World War II when a kind of unification began. ${ }^{73}$

In Sredačka Župa, old Serbian costumes were preserved, which drew the special attention of ethnologists. This Župa, because of its geographical isolation, was a separate ethnic entity, and its natural and economic conditions determined the material used in making costumes. Thanks to the livestock industry, wool was the basic material that protected the population from the rigors of the mountain climate and the

70 Milenko Filipović, Različita etnološka građa sa Kosova i Metohije, (Beograd: Naučno delo, 1967), 49.

71 Pribićević, Od gospodina do seljaka, 288.

72 Василије Козарац, Вукановић Татомир, Халими Кадри, Етнографска збирка Музеја Косова и Метохије, (Приштина, 1956), 379-410.

73 Jovanović, „Istorijsko, svakodnevno i privatno na prostoru Vardarske banovine“, 563-564. 
cold air. Other materials were obtained from the city: cotton, silk, colors and various ornaments. ${ }^{74}$

The Kosovo folk costume stood out from the neighboring regions. They wore hemp shirts, short vests, trousers with a belt and knitted socks. Men had short haircuts, wore forage caps (šajkača) and older men fur hats šubare. In Sredačka Župa, thez wore black hats with flat bottoms. Underwear was fairly wide, reaching to the ankles. At winter, men wore overcoats (gunj, z'ban) with long sleeves, which had a kind of hood (kacurec). Shoes opanci were made from raw leather - the skin of cattle or pigs. ${ }^{75}$ In Metohija, men had mostly taken on the Albanian costume, and wore white linen trousers, a red belt, džamadan and hat keče. ${ }^{76}$

Women's clothes were more luxurious than men's, embroidered and decorated. Women's costumes from Kosovo and Metohija ranked among the most beautiful and tasteful. J. Cvijić emphasized that the best Serbian costume was in the village Nerodimlje. ${ }^{77}$ Women made materials for their clothes, embroidered them, dyed them and made a variety of colors that were long-lasting and durable. Cloth and other fabrics were boiled in water in which they were dyed, while the embroidering material was placed in a jar after cooking and buried for 40 days for the color to become permanent. ${ }^{78}$

The main decoration of the female folk costume was embroidery. Women wore a long shirt to above the ankles made of of homespun cloth (cotton and hemp). The shirt was embroidered with woolen thread of various colors, metal thread and decorated with sequins and old silver coins. Only in Gornja Morava, the female costume stood out with its simplicity and lack of rich embroidery. ${ }^{79}$ Shirts differed by places where the

74 Vidosava Nikolić-Stojančević, Etnološka proučavanja Srba u Metohiji, (Leposavić: Institut za srpsku kulturu, 2003), 143-144. For more informations, see: Сима Тројановић, „Сретачка жупа и њена изумрла ношња“, Зборник радова посвећен Јовану Цвијићу, (Београд, 1924), 411-427; Видосава Краснићи, „Српска женска ношња на глави у Сретечкој жупи“, Гласник ЕИ САНУ (1), (Београд), 1952, 143159; Оливера Васић, Вез на сеоским женским кошуљама Метохије и Косова, каталог изложбе, (Београд, 1986).

75 Vukanović, Srbi na Kosovu, knj. 2, 96.

76 Milenko Filipović, „Etničke prilike u Južnoj Srbiji“, Spomenica 25-godišnjice oslobođenja Južne Srbije, 387-497, (Skoplje: Odbor za proslavu dvadesetpetogodišnjice oslobođenja Južne Srbije, 1937), 441.

77 Jovan Cvijić, Osnove za geografiju i geologiju Makedonije i Stare Srbije, knj. 3, (Beograd: Srpska kraljevska akademija, 1911), 1200.

78 Mitar Vlahović, „Sredačka župa“, Zbornik za etnografiju i folklor Južne Srbije i susednih oblasti, knj. 1, 27-52, (Skoplje: Štamparija Vasilija Dimitrijevića, 1931), 43.

Filipović, „Etničke prilike u Južnoj Srbiji“, 443. 
pattern originated (pazarka, lipljanka), the manner of embroidery (đurđev$a j k a$ ), pattern shapes (zmijana, lozana), and material (zlatana). ${ }^{80}$ Women placed below the throat a piece of cloth called podgrljanče. A daily short vest (jelek) was of brown cloth and without sleeves. Over the shirt, from the waist down they wore a futarka, which was a short skirt that reached to the middle of the thigh and its front was open. It was interesting that the darker shades of red were called "bright" because in this period these were bright colors. Over the futarka, they tied a pregača, a kind of apron, which was made from wool and was called differently in different villages (uvijača, bojča, skutača, pregljača). In Sredačka Župa, bošča was the same as a skirt and it was knee-length. Since the liberation from the Turks, the skirt from Northern Serbia "was embraced" throughout Kosovo. In the winter, women wore a gunj, a sleeved dress of dark cloth, decorated with ribbons. On a daily basis, they wore knee-high socks made of red and black knitted wool. Shoes opanci were the same as men's. Open-toed slippers from Prizren were appreciated and they were decorated with metal thread and sequins. ${ }^{81}$ The young women in Sredačka Župa wore a white scarf on their heads, and when they got older, a tas kapa - a red fez fastened by a ribbon around the head and a white scarf over it. ${ }^{82}$ In Vučitrn and surroundings, women wore a yellow scarf, and during the holidays a red cap with artificial yellow coins. ${ }^{83}$

Serbian women in towns (Peć, Đakovica, Prizren) had special clothes, similar to the costumes of Catholic Albanians and Serbs in Tetovo. These costumes were characterized by wide-legged trousers - šalva$r e$ and a jacket with fur (In Podrima that was characteristic). In the northern parts of Metohija the black color stood out in women's costumes (it was considered as a mourning of Kosovo and Marko Kraljević) and in the south near Prizren red colors were prominent. ${ }^{84}$

Combing hair was a significant feature of women. Thus, female children had their hair combed by older family members, usually their mothers. They wore various charms in their hair against the evil eye, which was especially the case for Muslims. Women washed their hair once or twice a month. The washing water was collected from clean rivers and combined with ced (made from ashes) or soap. Washing hair was not allowed on major holidays, nor on Fridays "for the health of brothers."

80 M. Vlahović, „Etnološka promatranja na Kosovu polju“, 511-517.

81 Nušić, Kosovo, 150-151.

82 Nikolić-Stojančević, Etnološka proučavanja Srba u Metohiji, 153-154.

83 M. Vlahović, „Etnološka promatranja na Kosovu polju“, 511-517.

84 Filipović, Različita etnološka građa sa Kosova i Metohije, 44-48. 
Cut hair was thrown into the fire so that it could not be used for witchcraft. After washing, they would put grease on their hair to make it shiny. Against hair loss, they would put a grass called češljakovina in the water in which they washed their hair. If they had a problem with baldness, they would apply oil that was prepared by letting a mouse decompose in a bottle. Brides received a comb as a gift on their wedding day, and they never loaned it to anyone for reasons of superstition. Other hair accessories included hairpins, small combs and hairclips (šnole) of various shapes and colors that were bought in the town. When a woman died, her comb was placed in the coffin along with her other belongings. ${ }^{85}$

An important and most beautiful part of women's costumes was jewelry. The most commonly used were silver coins, while gold and pearls were only used by rich women. Jewelry was more impressive and extravagant in the rich women, sometimes weighing more than ten kilograms. To make jewelry, manistras - tiny colored glass beads, kositrice - small metal circles, koskičke - small buttons and gold and silver wire were used. Zuk$v a$, a sour, wild apple was used to clean jewelry, because it made jewelry shine. ${ }^{86}$ Ears were pierced in early childhood with a needle, using nettles to numb them first. Earrings were mostly triangular or oblong with hanging chains, and the smaller ones were worn daily. ${ }^{87}$ They also wore metal bracelets and those made of manistras. ${ }^{88}$

As for the Albanian style of dressing, J. Cvijić said that Kosovo had no particular male clothes, because Serbs and Albanians, with small differences, dressed "equally Albanian." ${ }^{89}$ The most distinctive Albanian costume was in Rugova. ${ }^{90}$ Albanians wore tight trousers, a short vest on top of a shirt with a belt (there were two kinds available for purchase - from Đakovica and from Skoplje). Over that they wore mintan (white, black or red coat), and đurdina or ljurka (kind of a hood). On their head they most often wore a white hat keče or a thick brown hat. Albanian women wore a shirt, a long red vest below the knee and mintan. Footwear consisted of socks and opanci. Girls between 13 and 15 years old covered their faces. Older women wore feredžas (wide dress of black baize with sleeves and head cover). Catholic Serb women wore vests made of black cloth and black head scarfs. Muslim Serbs wore similar clothes as Albanians. Wom-

85 Nikolić-Stojančević, Etnološka proučavanja Srba u Metohiji, 143-147.

86 Ibid., 148-152.

87 Ibid., 158.

88 Vukanović, Srbi na Kosovu, knj. 2, 103.

89 Cvijić, Osnove za geografiju i geologiju Makedonije i Stare Srbije, knj. 3, 1200.

90 Anton Beriša, Kosovo: nekad i danas, (Beograd: Ekonomska politika, 1973), 339. 
en's costumes were under the influence of Turkish costumes, with šalvare, vests, and the face concealed. The Turks had a simple costume, trousers with narrow legs, a blue vest, mintan with sleeves, and winter coat kepe, gunj. Gypsies (Gabelji, Mađupi) were trying to blend in with the Muslim population in costume and customs. The Čerkezi (Circassians), of which there were several hundred in Kosovo (Gornje and Donje Stanovnice, Velika Reka and Miloševo), had preserved their customs and costumes, as well as their language, although they spoke Serbian, Turkish, and Albanian. ${ }^{91}$

In the period between the two wars, sewing and knitting machines were introduced in many villages. Courses were held in towns, among which the best known was the one in Peć that was attended by young women from all over Kosovo. "Terzije" - tailors from the villages adopted the sewing machine. ${ }^{92}$ In the cities, the influence of European fashion was starting to be noticed. The textile industry began to develop. In press advertisements hairdressing salons, boutiques, perfumes and cosmetics, businesses for steam cleaning and ironing clothes appeared. ${ }^{93} \mathrm{In}$ Sredačka Župa, folk costumes began to disappear under the influence of Prizren, because the town started to replace these costumes with their textile products. The cultural influence of the city penetrated not only from the immediate environment, but also with migrant workers, the so-called "pečalbari" from various distant cities. They were returning to their home towns and opening shops that had not existed in this region. Also, folk costumes, especially women's, were very complicated and difficult in terms of hygiene. Combing and making hairstyles was complicated, and they were combing 2-3 times a week, which made hair maintenance difficult..$^{94}$ Also, the younger generations were ashamed of parents who were still wearing folk costumes. ${ }^{95}$ Yet, many Muslims were reluctant to abandon their traditional clothes, even when it was necessary for practical reasons. ${ }^{96}$ This was particularly the case when it came to removing their traditional caps, for example when taking a picture for work ID, as well as at school. ${ }^{97}$ Muslims emphasized that the common religious prac-

91 Filipović, „Etničke prilike u Južnoj Srbiji“, 439-446, 487-496.

92 Vukanović, Srbi na Kosovu, knj. 2, 95-111.

93 Jovanović, „Istorijsko, svakodnevno i privatno na prostoru Vardarske banovine“, 572.

94 Nikolić-Stojančević, Etnološka proučavanja Srba u Metohiji, 161.

95 Vukanović, Srbi na Kosovu, knj. 2, 103.

96 Jovanović, „Istorijsko, svakodnevno i privatno na prostoru Vardarske banovine“, 564-565.

97 Archives of Yugoslavia (Arhiv Jugoslavije - AJ), 66-746-1201, Vrhovno muftijstvo Kraljevine SHS Ministarstvu prosvete, 14. oktobar 1929. 
tice was to maintain caps on their heads for occasions where they should pay homage to the city and public figures (as advised by the Grand Mufti of Belgrade). This issue of traditional caps was solved by the provincial school authorities in Kosovo, which strictly prohibited any interfering with the faith and national sentiments of Turkish and Albanian children. Muslim customs and religious rituals should be tolerated, because "from an Arnaut or Turk you could not create a Serb or a Croat." ${ }^{18}$ In this way, the Muslims preserved their more traditional way of dressing.

\section{Conclusion}

Between the two world wars, Kosovo and Metohija were marked by a patriarchal way of life. Large family communities, initial urbanization, the impact of traditions and folk customs, closed communities, illiteracy, and cultural unawareness were some of the features of life in this area. The lifestyle and the use of leisure time were determined by the fact that a large percentage of the people were living in rural areas and were engaged in farming and agriculture (76.30\%). However, changes were visible in the years leading up to World War II. In spite of largely closed communities, especially those in rural areas, modernization spread through both towns and villages. People living in rural areas were under the influence of nearby towns, and many of them began to work in factories and live in the urban areas. Consequently, changes were inevitable and unstoppable, until the outbreak of World War II, when the modernization of Kosovo and Metohija was partly disrupted. The war brought a new way of life and a new awareness among the people.

\section{Summary}

The period between the two world wars in Kosovo and Metohija was determined by the agricultural way of life in small farms and the cultural and educational backwardness of the population, especially in the countryside. They were preoccupied with rural chores and did not have the time or the opportunity for entertainment, such as townsfolk did. The people in the rural areas came together at slavas, religious holidays, church slavas, sabors, and litijas. Young women organized prelas, gatherings primarily at home. Another type of mainly female pastime and an interest-

98 AJ, 66-1401-1589, Izveštaj banskog školskog nadzornika o stanju narodnih škola u Vardarskoj banovini. 
ing folk phenomenon, especially in the villages, was singing folk songs while turning a pan on the table or on the floor. They did not celebrate birthdays because there were many family members, but they did celebrate "name days." The inhabitants of Kosovo and Metohija, especially Albanians, were famous for their hospitality. They often visited each other and socialized with music and conversation. The appearance of motion pictures was very important for the development of cultural life and entertainment in Kosovo and Metohija. Costumes began to disappear under the influence of nearby towns, which replaced folk costumes by producing more modern textiles and clothing products. The urban cultural influence came not only from local surroundings, but also with migrant workers, pečalbari, from various distant places. The Muslim population found it more difficult to accept the changes because they were a closed community. Consequently, changes were inevitable and unstoppable, until the outbreak of World War II, when the modernization of Kosovo and Metohija was partly disrupted. The war brought a new way of life and a new awareness among the people.

\section{Sources and Literature}

- Arhiv Jugoslavije. Fond Ministarstva prosvete Kraljevine Jugoslavije (66).

- Aleksić, Jovan. „Srpska novinska glasila u Kosovskoj Mitrovici od 1918 do 1941. godine“. Hronotop Kosova i Metohije u nauci i umetnosti, ur. Dragan Tančić, Jamina Ahmetagić, Dalibor Elelzović, 493-507. Leposavić: Institut za srpsku kulturu, 2018.

- Avramovski, Živko. „Granice Kraljevine SHS sa Albanijom“. Istorija 20. veka 1-2/1992, 35-49.

- Barjaktarović, Mirko. „Dvovjerske šiptarske zadruge u Metohiji“. Zbornik radova EI SANU 1/1950, 197-209. (cyrillic)

- Barjaktarović, Mirko. „Porodična zadruga Bali Čuke iz Rugove“. Glasnik Muzeja Kosova i Metohije 1/1956, 275-283. (cyrillic)

- Bataković, Dušan T. Istraga oružja u Ibarskom Kolašinu 1901. godine. Beograd, 1990.

- Bataković, Dušan. Pokušaj otvaranja srpskog konzulata u Prizrenu (18981900). Beograd: Istorijski institut, 1984.

- Beriša, Anton. Kosovo: nekad i danas. Beograd: Ekonomska politika, 1973.

- Bjelajac, Mile. Vojska Kraljevine SHS: 1918-1921. Beograd: Narodna knjiga, 1988.

- Bogdanović, Dimitrije. Knjiga o Kosovu. Beograd: SANU, 1986. 
- Bondžić, Dragomir. „Učitelji u multietničkim sredinama: primer Kosova i Metohije 1945-50“. Obrazovanje i uloga učitelja u srpskom društvu kroz istoriju (XVIII-XX vek). Sombor: Pedagoški fakultet, 2009.

- $\quad$ Božović, Grigorije. Slike Kosova i Metohije. Priština: Narodna i univerzitetska biblioteka, 1998.

- $\quad$ Cvijić, Jovan. Osnove za geografiju i geologiju Makedonije i Stare Srbije, knj. 3. Beograd: Srpska kraljevska akademija, 1911.

- Definitivni rezultati popisa stanovništva po maternjem jeziku od 31. januara 1921. Beograd: Opšta državna statistika, 1932.

- Definitivni rezultati popisa stanovništva od 31. marta 1931, knj. 4. Beograd: Opšta državna statistika, 1940.

- $\quad$ Denda, Petar, Pavle Ivanov Dželetović. Suvi Do. Beograd: Odbor za proučavanje sela SANU, 1993.

- Dimić, Ljubodrag. Kulturna politika Kraljevine Jugoslavije, knj. 1. Beograd: Stubovi kulture, 1996.

- $\quad$ Dimić, Ljubodrag, Đorđe Borozan.Jugoslovenska država i Albanci, tom 1. Beograd: Službeni list SRJ, Arhiv Jugoslavije, Vojno-istorijski institut, 1998.

- $\quad$ Filipović, Milenko. „Etničke prilike u Južnoj Srbiji“. Spomenica 25-godišnjice oslobođenja Južne Srbije, prir. Aleksa Jovanović, 387-497. Skoplje: Odbor za proslavu dvadesetpetogodišnjice oslobođenja Južne Srbije, 1937.

- $\quad$ Filipović, Milenko. Različita etnološka građa sa Kosova i Metohije. Beograd: Naučno delo, 1967.

- $\quad$ Filipović, Milenko. „Tetovisanje u Južnoj Srbiji“. Godišnjak skopskog Filozofskog fakulteta (2), 1936, 76-95.

- Hadri, Ali. „Društveno-ekonomske, političke, kulturno-prosvetne i zdravstvene prilike“. Kosovska Mitrovica i okolina, 107-110. Priština: Institut za istoriju Kosova, 1979.

- Hadži-Vasiljević, Jovan. Arbanaska liga: arnautska kongra i srpski narod u Turskom Carstvu (1878-1882). Beograd: Uredništvo Ratnika, 1909.

- Halimi, Kadri. „Beleške o običaju gostoprimstva kod Albanaca na Kosovu“. Glasnik Muzeja Kosova 10/1970, 345-353. (cyrillic)

- Hrabak, Bogumil. „Ideje o arbanaškoj autonomiji i nezavisnosti 1876-1880“. Istorijski časopis XXII-XXIII (1978-1979), 159-192.

- Hrabak, Bogumil. „Kosovo prema Mladoturskoj revoluciji 1908“. Obeležja 5/1974, 107-149.

- Hrabak, Bogumil, Dragoslav Janković. Srbija 1918. Beograd: Sedma sila, 1968.

- Jagodić, Miloš. Srpsko-albanski odnosi u Kosovskom vilajetu (1878-1912). Beograd: Zavod za udžbenike, 2009.

- Jagodić, Miloš. Uređenje oslobođenih oblasti Srbije: 1912-1914: pravni okvir. Beograd: Istorijski institut, 2010. 
- Jovanović, Vladan. „Istorijsko, svakodnevno i privatno na prostoru Vardarske banovine". Privatni život kod Srba u dvadesetom veku, prir. Milan Ristović, 543-578. Beograd: Clio, 2007.

- $\quad$ Kozarac, Vasilije i dr. Etnografska zbirka Muzeja Kosova i Metohije. Priština, 1956. (cyrillic)

- Krasnići, Mark. „Šiptarska porodična zadruga u Kosovsko Metohijskoj oblasti“, Glasnik Muzeja Kosova i Metohije 4-5/1959-1960, 137-171.

- $\quad$ Krasnići, Vidosava. „Srpska ženska nošnja na glavi u Sretečkoj župi“. Glasnik EI SANU 1/1952, 143-159.

- $\quad$ Krstić, Đorđe. Kolonizacija u Južnoj Srbiji. Sarajevo: Đ. Krstić, 1928.

- $\quad$ Maliković, Dragi. Kačački pokret na Kosovu i Metohiji 1918-1924. Priština: Institut za srpsku kulturu, 2005.

- $\quad$ Mikić, Đorđe. „Albanci i Srbija u Balkanskim ratovima 1912-1913“. Istorijski glasnik 1-2/1986, 55-80.

- $\quad$ Mikić, Đorđe. Društvene i ekonomske prilike kosovskih Srba u XIX i početkom XX veka: od čifčijstva do bankarstva. Beograd: SANU, 1988.

- Mitrović, Andrej. „Albanci u politici Austro-Ugarske prema Srbiji 19141918“. Srbi i Albanci u XX veku, prir. Andrej Mitrović, 79-104. Beograd: SANU, 1991.

- Nikolić, Goran. „Kretanje stanovništva Kosova i Metohije između dva svetska rata“. Nova srpska politička misao 2006 (debate). Datum pristupa 14. 6.2019. http://starisajt.nspm.rs/Debate/2006_nikolic_kos33.htm

- $\quad$ Nikolić-Stojančević, Vidosava. Etnološka proučavanja Srba u Metohiji. Leposavić: Institut za srpsku kulturu, 2003.

- $\quad$ Nušić, Branislav. Kosovo. Priština: Panorama, 2007.

- Obradović, Milorad. Agrarna reforma i kolonizacija na Kosovu 1918-1941. Priština: Institut za istoriju Kosova, 1981.

- $\quad$ Osnovni statistički podaci o razvoju i stanju školstva u Federativnoj Narodnoj Republici Jugoslaviji: dokumentacija uz Deklaraciju o sistemu obrazovanja i vaspitanja u FNRJ. Beograd: Savezna Narodna skupština, 1957.

- Pavlović, Aleksandar. "Naselja Srba i Crnogoraca kolonizovanih na Kosovu i Metohiji u period između 1918 i 1941”. Baština 25/2008, 219-237.

- Pavlović, Momčilo, Dragomir Bondžić, Miomir Gatalović, Ivana Pantelić, Goran Antonić, Ratomir Milikić. Kosovo i Metohija: vek važnih događaja: 19122012. Beograd: Instutut za savremenu istoriju, 2012.

- Pribićević, Adam. Od gospodina do seljaka. Zagreb: Srpsko kulturno društvo Prosvjeta, 1996.

- Rajović, Radošin. Autonomija Kosova: istorijsko-pravna studija. Beograd: Ekonomika, 1985.

- $\quad$ Samardžić, Radovan i dr. Kosovo i Metohija u srpskoj istoriji. Beograd: Srpska književna zadruga, 1989.

- Savić, Milivoje. Naša industrija i zanati, VII deo. Beograd: Izdanja Ministarstva trgovine i industrije, 1929. 
- $\quad$ Savremenici o Kosovu i Metohiji: 1852-1912, prir. Dušan T. Bataković. Beograd: Srpska književna zadruga, 1988.

- Simeunović, Vladimir. Stanovništvo Jugoslavije i socijalističkih republika: 1921-1961: ukupno stanovništvo, polna i starosna struktura. Beograd: Savezni zavod za statistiku, 1964.

- $\quad$ Slavković Mirić, Božica. Političke, ekonomske i kulturne prilike na Kosovu i Metohiji 1929-1941. Beograd: Prosveta, Princip, 2018.

- $\quad$ Službene novine Kraljevine SHS, br. 22, (Beograd), 1922.

- $\quad$ Stojančević, Vladimir. Srbi i Arbanasi 1804-1912. Novi Sad: Prometej, 1994.

- $\quad$ Stulli, Bernard. Albansko pitanje (1875-1882). Doktorska disertacija, Filozofski fakultet, Sveučilište u Zadru.

- $\quad$ Tasić, Dmitar. Rat posle rata: Vojska Kraljevine Srba, Hrvata i Slovenaca na Kosovu i Metohiji i u Makedoniji: 1918-1920. Beograd: Utopija: Institut za strategijska istraživanja, 2008.

- Trojanović, Sima. „Sretečka župa i njena izumrla nošnja“. Zbornik radova posvećen Jovanu Cvijiću, ur. Pavle Vujević, 411-427. Beograd: Državna štamparija, 1924.

- Urošević, Atanasije. „Agrarna reforma i naseljavanje“. Spomenica 25-godišnjice oslobođenja Južne Srbije, 819-833. Skoplje: Odbor za proslavu dvadesetpetogodišnjice oslobođenja Južne Srbije, 1937.

- $\quad$ Urošević, Atanasije. Gornja Morava i Izmornik. Priština: Jedinstvo, 1993.

- Urošević, Atanasije. O Kosovu - antropogeografske studije i drugi spisi. Priština: Narodna i univerzitetska biblioteka „Ivo Andrić“, Institut za srpsku kulturu, Gnjilane: Knjižara „Sveti Sava“, 2001.

- Vasić, Oliver. Vez na seoskim ženskim košuljama Metohije i Kosova, katalog izložbe. Beograd: Etnografski muzej, 1986.

- Vlahović, Mitar. „Etnološka promatranja na Kosovu polju“. Južni pregled, 11. novembar 1930.

- Vlahović, Mitar. „Sredačka župa“. Zbornik za etnografiju i folklor Južne Srbije i susednih oblasti, knj. 1, ur. Vojislav S. Radovanović, 27-52. Skoplje: Štamparija Vasilija Dimitrijevića, 1931.

- Vlahović, Petar. „Etnološke odrednice Kosova i Metohije“. Zbornik radova Kosovo i Metohija u svetlu etnologije, ur. Mirjana Menković, 220-228. Beograd: Etnografski muzej, Muzej u Prištini, Centar za očuvanje nasleđa Kosova i Metohije - Mnemosyne, 2004.

- Vlahović, Petar. „Etnološko proučavanje Kosova i Metohije“. Zbornik okruglog stola o naučnom istraživanju Kosova, ur. Pavle Ivić, 127-139. Beograd: Srpska akademija nauka i umetnosti, 1988.

- Vlahović, Petar. „Narodno gostoprimstvo na Kosovu i Metohiji“. Beograd, 1967.

- Vojvodić, Miloš. „Berlinski kongres i Prizrenska liga“. Istorijski glasnik 1-2, 1989, 1-20. 
- Vukanović, Tatomir. Drenica - druga srpska Sveta Gora. Priština: Muzej u Prištini, Narodna i univerzitetska biblioteka, 1998.

- Vukanović, Tatomir. „O pevačima narodnih pesama u Drenici“. Prilozi proučavanju narodne poezije (1, sv. 3), 1934, 156-158.

- Vukanović, Tatomir. „Pevanje narodnih pesama uz okretanje tepsije“. Glasnik Muzeja Kosova i Metohije (1), 1956, 118-157.

- Vukanović, Tatomir. Srbi na Kosovu, knj. 2. Vranje: Nova Jugoslavija, 1986.

- Vukadinović, Zoran, Milovan Bogavac. Srpska prosveta i kultura u Kosovskoj Mitrovici: 1836-1941. Priština: Institut za srpsku kulturu, 2001.

- „Zakon o nazivu i podeli kraljevine na upravna područja“. Zbirka Službenog glasnika, sv. XXXVI, (Split), 1929.

- $\quad$ Politika (cyrillic)

- Pravda (cyrillic)

- $\quad$ Vardar (cyrillic) 


\title{
Резиме
}

Божица Славковић Мирић

\section{Мода и забава на Косову и Метохији у периоду између два светска рата}

\begin{abstract}
Апстракт: Уз помоћ одговарајуће литературе, штампе и историјских извора у раду су анализирани и описани менталитет и понашање људи на Косову и Метохији у периоду између два светска рата. Свакодневица је била одређена пољопривредним начином живота на ситном поседу, као и културном и просветном заосталошћу становништва, нарочито на селу. Тешко су продирали модерни утицаји из оближњих градова, јер је сељак љубоморно чувао свој начин живота, обичаје и традицију. Ипак, позитивне особине као што су гостољубивост и духовитост, затим шароликост ношњи, традиција, велики број различитих обичаја, народна књижевност и предања представљају само неке од значајних одлика становништва Косова и Метохије сачуваних до данашњих дана.
\end{abstract}

Кључне речи: Косово и Метохија, међуратни период, мода, забава, свакодневни живот

Период између два светска рата на Косову и Метохији карактерисала је пољопривредна делатност великог броја становништва, чиме је била одређена свакодневица људи пре свега на селу. Заокупљени пословима, нису имали времена нити могућности за забаву каква је постојала у граду. Људи на селу окупљали су се на славама, о већим празницима, црквеним славама, саборима, литијама. Девојке су се увече дружиле на прелима, а интересантна забава било је певање уз тепсију која се окретала на поду. Прослава рођендана није било јер је владало сиромаштво, али су се славили имендани. Становници Косова и Метохије, нарочито Албанци, били су чувени по својој гостољубивости. Често су се међусобно посећивали и дружили на тај начин уз музику и разговор. У граду је културно-забавни живот почео да се развија захваљујући појави бископа, али и већој посвећености људи позориштима. Модеран градски начин облачења и понашања почео је да утиче на сеоску моду и да замењује народну 
ношњу конфекцијским производима. Муслиманско становништво теже је прихватало промене због традиционалне затворености и религиозности. Ипак, модернизација друштвеног живота у годинама пред Други светски рат била је видљива. Промене су биле неизбежне и незаустављиве, све до избијања рата, када је модернизација на Косову и Метохији делимично прекинута, а рат је донео неки нови начин живота и нову свест људи. 